American Journal of Applied Sciences 6 (5): 943-951, 2009

ISSN 1546-9239

(C) 2009 Science Publications

\title{
Effective Ventilation Parameters and Thermal Comfort Study of Air-conditioned Offices
}

\author{
Roonak Daghigh and Kamaruzzaman Sopian \\ Solar Energy Research Institute, University Kebangsaan Malaysia (UKM)
}

\begin{abstract}
The study presents objective and subjective studies of thermal comfort levels and ventilation characteristics of two air-conditioned postgraduate study offices. The observations were performed at the offices of Department of Electrical and Electronic Engineering, in University Putra Malaysia. Thermal comfort variables were measured while the students answered a survey on their sensation of the indoor climate. Concurrently, tracer gas analysis, based on concentration decay method, is employed to determine air exchange rate, age of air and air exchange effectiveness. During the air conditioner is working, the study offices had not conditions within the comfort zone, of ASHRAE standard 55 causing occupants to report cold thermal sensations and the objective data analysis showed that the offices were uncomfortable. The thermal neutralities were significantly higher that proposed by ASHRAE Standard 55:1992. The monitored air exchange rates are indicated that the provisions of outside air for ventilation based on design occupancy are adequate for these two study offices. In addition, questionnaires were completed by the students in order to provide a subjective assessment of thermal comfort and indoor air quality. Finally, the outcomes of over 30 surveys for each office responses to the thermal comfort questions are presented and discussed.
\end{abstract}

Key words: Thermal comfort, air exchange effectiveness, tracer gas decay method, air- conditioning, objective study, subjective approach

\section{INTRODUCTION}

Malaysia is located in the tropical region with a hot and humid climate where a large number of the buildings served by air-conditioning systems. Over the past three decades, Malaysia has been experiencing fast economic and social transformation as well as rapid urban growth. The distribution of housing categories will undergo changes in the years ahead. High and medium density housing will be widespread given the high cost of land and constructions on urban space to cope with housing demand. In recent years, Malaysia's energy consumption has increased, where the corresponding energy demand would significantly increase in the next coming years. Primary concern should be given to making sure that the people inside are happy and comfortable to stay-they are not too hot or too cold .Through the knowledge of thermal comfort behavior of human and energy utilization behavior of buildings, the best strategy can be adopted ${ }^{[1]}$.

The objectives in ventilating a building are to efficiently distribute ventilation air to the occupied zones and to remove or dilute indoor contaminants. The performance of a ventilation system is judged by its local mean age of air, contaminant removal effectiveness, air exchange effectiveness and the thermal conditions. Both thermal comfort and air quality can have important impacts on productivity. Thermal condition in study office rooms has to be considered carefully mainly because of the high occupant density in these areas and because of the negative influences that an unsatisfactory thermal environment has on learning and performance. In tropical regions, the hot and humid climate may have an adverse impact on occupant comfort indoors ${ }^{[2]}$.

The significance of maintaining good indoor climate is self-evident when one considers that in every modern economy a significant part of the Gross National Product (GNP) is earned by people working in office buildings. In view of the importance of thermal comfort and indoor air quality, the design challenge is to achieve acceptable indoor environmental conditions for individual building occupant ${ }^{[3]}$.

In this study thermal comfort levels and ventilation parameters of two mechanically ventilated study offices were evaluated and compared with ASHRAE standard $62^{[4]}$ and AHRAE 55 and ISO $7730^{[5,6]}$ respectively. The neutral temperatures were calculated and the

Corresponding Author: Roonak Daghigh, Solar Energy Research Institute, University Kebangsaan Malaysia, 43600, Bangi, Selangor, Malaysia Tel: +603-89214596 Fax: +603-89214593 
student's perceptions of the degree of comfort in postgraduate study offices were investigated.

\section{THERMAL COMFORT STUDIES IN MALAYSIA}

Based on the literature review done, there is few thermal comfort studies conducted in Malaysia before the 1990s. According to the $\mathrm{e}^{[7,8]}$ the proposed temperature for air-conditioned non-residential buildings is $23-26^{\circ} \mathrm{C}$. These Figures are similar to ${ }^{[5,6]}$. However, since 1990's with the increasing of energy usage in commercial sector, more research have been conducted in the area of thermal comfort to find means to provide comfortable indoor environments to reduce energy consumption and costs. Studies have shown that an increase in temperature indoor setting of $1.5^{\circ} \mathrm{C}$ gave $15.8 \%$ energy saving ${ }^{[9,10]}$.

A study in a controlled climate chamber involving 130 university students aged between 18-24 conducted in $1993^{[11]}$. All subjects were engaged in light activity of 1.0 met and clothes of 0.5 Clo value. The air velocity was $0.1 \mathrm{~m} \mathrm{~s}^{-1}$ and relative humidity $50 \%$. The result showed that the neutrality temperature was $28.2^{\circ} \mathrm{C}$ at $50 \%$ relative humidity.

A study on a factory involving male university students and workers aged between 18 to 40 at three different environmental conditions conducted. At each condition, four different physical levels of work were tested. He concluded that majority was more tolerant towards the higher air temperatures i.e., $23-29^{\circ} \mathrm{C}^{[12]}$.

A survey conducted and measured the indoor environmental parameters to study and determine the comfort conditions of college students in their naturally ventilated classrooms in Shah Alam. A mean temperature of $29.8^{\circ} \mathrm{C}$ and mean air movement of 0.27 $\mathrm{m} \mathrm{s}^{-1}$ were experienced by the subjects at average $65 \%$ humidity. The neutrality temperature calculated was $27.4^{\circ} \mathrm{C}$ which is $1.4^{\circ} \mathrm{C}$ lower than mean room temperature. The result agrees with Humphreys' adaptive model where the comfort temperature is closed to the mean indoor temperature ${ }^{[10]}$.

Explained $^{[1]}$ that a study on 21 year old university students showed the comfort range of $24.5-28^{\circ} \mathrm{C}$ with $73 \%$ humidity. The neutrality temperature was $26.3^{\circ} \mathrm{C}$. However, this result is a combination of air-conditioned and naturally ventilated rooms.

In another research eleven air-conditioned offices were studied. The results showed a comfort range of 20.8-28. $6^{\circ} \mathrm{C}$ which was wider than the recommended range by ${ }^{[5,8]}$. A study to compare the results of eight thermal comfort studies done by Sh. Ahmad, 2002 in various buildings suggested that a higher thermal comfort range for Malaysians than ${ }^{[5,6]}$, which indicates that Malaysians are acclimatized to higher environmental temperatures.

A study conducted to determine whether the demonstration low energy office (LEO) is thermally comfortable as an office working space. Result showed that office is generally thermally comfortable in the morning with PPD values of $18.19 \%$ and was becoming cool in the morning and afternoon with PPD values of 24.12 and $21.56 \%$ of PPD respectively ${ }^{[1]}$.

The issues of thermal comfort and passive design strategies in urban housing in the Klang Valley area explored. A study of comfort (using software code TAS) was conducted on apartment units in medium rise housing block. The results show that these units are uncomfortable especially during the day ${ }^{[12]}$.

Typical strategies to naturally improve comfort in a climate which is hot and humid without air conditioning described $^{[13]}$. The result showed that the prospect for not using air conditioning in rural area is relatively high when good design was adopted.

A preliminary study of thermal comfort in Malaysia's single storey terraced houses conducted. The thermal environment and comfort conditions were investigated using field measurement and CFD technique. Validation of CFD Fluent was carried out through the comparison of field measurements. Comparison of the results between simulations and measurements illustrated a good agreement. The simulations were performed on a selected day in a oneyear climate condition. The results indicated that the design of single storey terraced houses is not effective in providing natural ventilation for achieving thermal comfort $^{[14]}$.

\section{THERMAL COMFORT STUDIES IN SOUTH EAST ASIA}

Webb and Ellis ${ }^{[15,16]}$ pioneered the thermal studies in Singapore. In 1990s, field experiments in naturally ventilated office buildings in Bangkok conducted; Thailand and results indicated a neutrality of $28.5^{\circ} \mathrm{C}$ Effective Temperature (ET); while $24.5^{\circ} \mathrm{C}$ ET was observed in air-conditioned buildings ${ }^{[17]}$. Field studies conducted in 1990 in Singapore involved 235 subjects from air-conditioned office buildings showed that the neutrality temperature was $24.2^{\circ} \mathrm{C}$ which was also similar to Busch's result.

A study conducted in Singapore involving 32 students. The result showed that the neutrality temperature was $25.4^{\circ} \mathrm{C}$. Another study conducted a year later involving 98 students found that the acceptable comfort zone was $27.6^{\circ} \mathrm{C}$ at $70 \%$ relative 
humidity and $27.9^{\circ} \mathrm{C}$ at $35 \%$ relative humidity ${ }^{[18]}$.

The comfort temperature for Malaysia office workers was $24.7^{\circ} \mathrm{C}$ which generally agreed with other field studies in air-conditioned environments in the tropics i.e., in the range $24.2-24.5^{\circ} \mathrm{C}$. However, the average measured office air temperature was $23.1^{\circ} \mathrm{C}$ showing that Malaysian air conditioning designers and operators did not adhere to the recommended indoor design temperatures ${ }^{[19,20]}$.

A study in Bangkok conducted during the hot season in April and wet season in July involving more than 1100 people. He compared naturally ventilated with air conditioned offices. The study showed that the neutrality temperature for naturally ventilated buildings was $27.4^{\circ} \mathrm{C}$ while air conditioned buildings was $24.7^{\circ} \mathrm{C}$. The thermal acceptability of all subjects was $22-30.5^{\circ} \mathrm{C}$, an increase of $4^{\circ} \mathrm{C}$ from the upper limit of ASHRAE comfort zone ${ }^{[20]}$.

A field study conducted in Jakarta involving almost 600 workers from seven office buildings which consisted of a naturally ventilated, a hybrid and five air conditioned. The neutrality temperature was $26.4^{\circ} \mathrm{C}$ which was $2.5^{\circ} \mathrm{C}$ higher than those recommended by ISO and ASHRAE. A comparative analysis of all the previous thermal comfort studies done in South East Asia made and concluded that people living in the warm and humid tropical countries prefer similar neutral temperatures around $25-30^{\circ} \mathrm{C}$. In comparison to the ${ }^{[5,6]}$ recommended temperature of $23-26^{\circ} \mathrm{C}$, these figures are $2-4^{\circ} \mathrm{C}$ higher. A field study on thermal comfort and building energy has been carried out in Jakarta. Some 596 office workers working in seven multi-storey office buildings participated in this study. This study also reveals that comfort conditions could be achieved without unnecessary extra cooling in air conditioned buildings ${ }^{[21]}$.

A study of 288 subjects in Bangkok conducted at different thermal conditions using varied air velocity of $0.2-3 \mathrm{~m} \mathrm{~s}^{-1}$ in naturally ventilated spaces. The results showed that the comfort temperature was $27.2-0.2 \mathrm{~m} \mathrm{~s}^{-1}$ and the comfort temperature increases as the velocity increases $^{[22]}$.

Two IAQ Audits studies conducted in Singapore. Parts of these audits consist of examination of thermal comfort parameters. The air dry-bulb temperature recorded in one office was ranged between $22.1^{\circ} \mathrm{C}$ and $22.48^{\circ} \mathrm{C}$. The air dry-bulb temperature recorded in another office was between $22.9^{\circ} \mathrm{C}$ and $23.6^{\circ} \mathrm{C}^{[2,24]}$.

A field study was conducted in classrooms in Singapore, which were mechanically ventilated by fans, to assess their thermal conditions during the students' lesson hours. Objective data analysis showed that none of the classes had thermal conditions falling within the comfort zone of ASHRAE standard 55. Occupants found temperature range beyond the comfort zone acceptable. This suggests that the standard is not applicable in free-running buildings in the local climate. Classroom occupants generally accepted cool thermal sensations more readily than warm thermal sensations $^{[25]}$.

A study on local thermal sensation (LTS) and comfort in a field environmental chamber (FEC) served by displacement ventilation (DV) system in Singapore was participated by 60 tropically acclimatized subjects (30 male and 30 female) who were engaged in sedentary office work for $3 \mathrm{~h}$. Subjects were exposed to three vertical air temperature gradients. The results show that in a space served by DV system, at overall thermal sensation close to neutral, local thermal discomfort decreased with the increase of room air temperature ${ }^{[26]}$.

\section{PREVIOUS IAQ AND VENTILATION EFFECTIVENESS RESEARCHES IN MALAYSIA AND SOUTH EAST ASIA}

In Malaysia, an indoor air quality research in industrial buildings was conducted ${ }^{[27]}$.Measurements of concentrations level of main indoor contaminants and air exchange rate were carried out. Air exchange rate $(\mathrm{ACH})$ ranged from $0.1-0.3$. This study was conducted during the period when the country was facing the environmental haze.

An IAQ audit methodology was developed and adopted to establish the IAQ profile of a building. A case-study was used to demonstrate the application of the IAQ audit and evaluate its comprehensiveness and usefulness to the building owners or facility managers. This audit was conducted in the administration offices of a hospital building ${ }^{[23]}$.

The development and application of an IAQ audit methodology for the tertiary institutional buildings conducted. The IAQ audit consists of monitoring of thermal comfort parameters, microbial counts, dust particles and the concentrations of carbon dioxide $\left(\mathrm{CO}_{2}\right)$, carbon monoxide $(\mathrm{CO})$, formaldehyde $(\mathrm{HCHO})$ and total volatile organic compounds (TVOCs). Air exchange rate, ventilation effectiveness and age of air were also investigated The IAQ results collected in this study was used to develop an IAQ database for institutional buildings in Singapore. This is beneficial for development of guidelines for good indoor air quality in institutional buildings in Singapore ${ }^{[24]}$.

Air exchange effectiveness values in a seven-storey office building calculatesd. Tracer gas analysis, based 
on concentration decay method, was employed to determine these values. The results indicate airflow patterns in the occupied zones which approximate perfect mixing. The measured concentration levels of indoor air pollutants are also found to be within reasonable limits ${ }^{[28]}$.

A comprehensive indoor air quality (IAQ) and energy studies in a hot and humid climate (Singapore) conducted and data from both objective and subjective measurements presented. Performance indices, such as ventilation index, energy index and the newly introduced indoor pollutant standard index (IPSI) are envisaged as practical tools for a quick assessment in exploring the integrated issues of IAQ and energy in buildings ${ }^{[29]}$.

\section{MATERIALS AND METHODS}

In order to determine the thermal comfort, objective and subjective approaches were carried out in two postgraduate study offices (Fig. 1 and 2) at the eighth level of block B office building faculty of engineering in University Putra Malaysia (UPM). The Rooms are equipped with air-conditioners.

Four environmental variables were measured using measuring physical quantities instruments (BABUCA): air velocity, relative humidity, dry bulb temperature and mean radiant temperature. Objective physical measurements were carried out at one point inside in the middle of each study offices; all measurements were taken at a height of 1.1 meter above the floor, which represents the height of the occupant at seated level. The samples were recorded every one minute interval. Having measured the environmental parameters, the two personal parameters, metabolic rate and clothing insulation were estimated in accordance with ISO 7730. In this study, the metabolic rate is set to be $1.2 \mathrm{met}^{[6]}$ which is sedentary activities (office, dwelling, school, laboratory) whereas the Clo-value (thermal resistance) is set to be 0.5 where the males were wearing underpants, shirt with short sleeves, light trousers, light socks and shoes. The females were wearing baju kurong, which is cotton or silk with light cotton undergarments and a lightweight scarf. Figure 4 shows the approximate location of the sampling point. Measurements of thermal comfort parameters conducted in the middle of October, 2006.

The tracer gas concentration decay technique was used to experimentally study air exchange rate, age of air and air exchange effectiveness. The age of air concept was used to evaluate the air exchange effectiveness. The first step in obtaining a method for

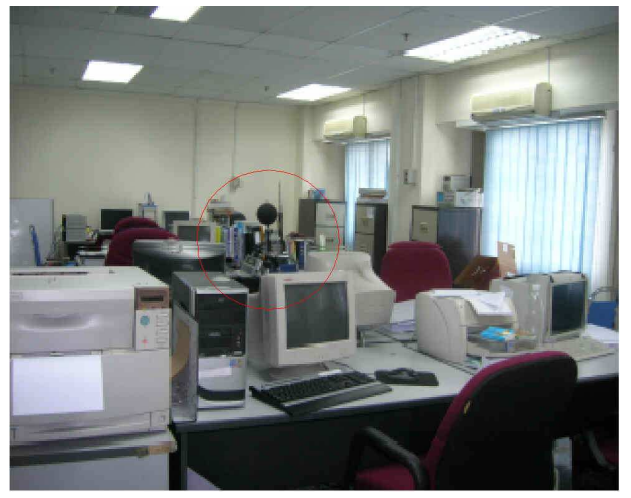

Fig. 1: View o postgraduate study office room 1, BABUCA

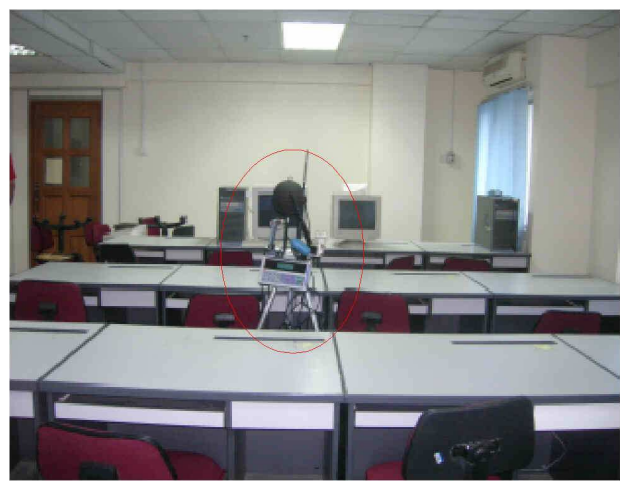

Fig. 2: View of postgraduate study office room 2, BABUCA and IAQmeter

field measurement of Air Exchange Rate (ACH), Age of Air and Air Exchange Effectiveness (AEE) was to select a tracer gas that is relatively harmless and is easily detectable. Carbon Dioxide $\left(\mathrm{CO}_{2}\right)$ is the tracer gas that best fulfills the toxicity requirement and can be detected accurately and economically using direct reading instruments, it was chosen because its density almost similar to density of air. $\mathrm{CO}_{2}$ is also a gas recommended as an index of global room ventilation by international standards. Because of these advantages, $\mathrm{CO}_{2}$ was identified as the best tracer gas to be used for this research. The source is the $\mathrm{CO}_{2}$ type fire extinguisher; $2.27 \mathrm{~kg}$ tanks were used during the tests or designated cylinder.

The next step was the selection of an appropriate injection scheme for the source of $\mathrm{CO}_{2}$. An intermittent injection scheme was preferred over a continuous injection scheme. With this scheme, the source was activated for only a short period of time for $15 \mathrm{~min}^{[29]}$ to avoid disturbing the background $\mathrm{CO}_{2}$ concentrations in the office rooms. This was made by injecting the gas 
until room concentrations have become uniform using a desk fan. The concentration decay of tracer gas measured using four indoor air quality (IAQ) meters. Two of the IAQ meters were located beside the BABUCA meters in the middle of study offices and two of them were placed at the system exhausts.

Occupants must be viewed as important contributors throughout the assessment process as they are the source of complaints and a potential source of useful information that can help in assessing the extent of the problem and identifying solutions. Furthermore, occupant input during experiment phase is essential for evaluating thermal conditions of space and the effectiveness of implemented solutions. People input can be directly obtained through interviews or through questionnaire surveys. Therefore, Assessment of the thermal comfort in two study offices was based on responses to a questionnaire survey, which was administered simultaneously with the physical measurements in each office. A total of 30 respondents participated in the survey for each office; all of them were postgraduate students.

The dominant gender distribution sampled was male $(66.6 \%)$ for each office, The total response rate was $100 \%$. Prior to the survey, the subjects would have been seated at their chairs for approximately $30 \mathrm{~min}^{[30]}$ with mostly sedentary activities. Sufficient time for body precondition in each survey was necessary to maintain respondent's metabolic rate $(\mathrm{M})$ at the same level throughout the study which was estimated to be equal to 1.2 met.

\section{RESULTS AND DISCUSSION}

Thermal comfort assessment: From the thermal comfort parameters, Predicted mean vote (PMV) and percentage people dissatisfied (PPD) for two airconditioned postgraduate study office by using InfoGap together with Microsoft Excel were calculated. The ranges of PMV for postgraduate study office 1 and 2 were between (-1.7)-(-1.5) and (-1.2)-(-1.4) and PPD were in the ranged between $50-60 \%$ and $35-45 \%$, respectively as shown in Fig. 3. Based on ISO 7730, the comfort range was taken to be the conditions when the PMV has the values between -1 and +1 . These analysis's resulted from the measurement in the middle of October, 2006 from 9.00 a.m. to 17.00 p.m. when air-conditioner was on all the time, These results show that more than half of the occupants felt thermally uncomfortable in the office space 1 during sedentary activities at that period of time with an average temperature of $21.5^{\circ} \mathrm{C}$ and relative humidity of $53 \%$. The office 2 is thermally uncomfortable with anl

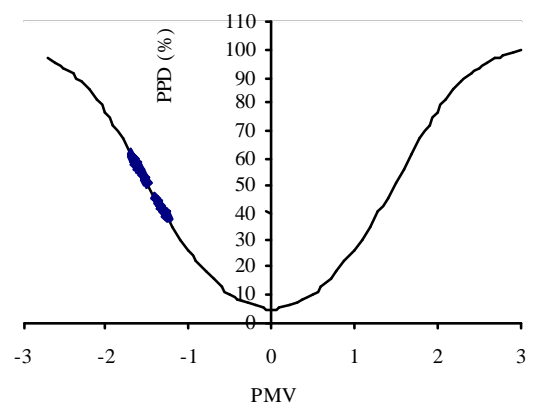

Fig. 3: Two air-conditione offices office Predicted Percentage of Dissatisfied (PPD) as a function of Predicted Mean Vote (PMV).

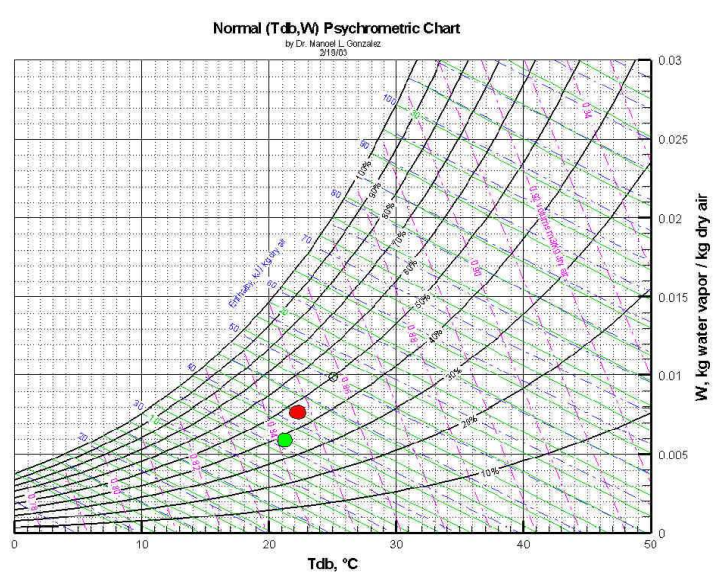

Fig. 4: Thermal comfort range based on psychometric chart-ASHRAE 55

average temperature of $22.6^{\circ} \mathrm{C}$ and relative humidity of $59 \%$.

The ASHRAE Standard 55-1992 states that the comfort zone for summer conditions, air temperature to be between $23-26^{\circ} \mathrm{C}$ and relative humidity between 20 $60 \%$. Figure 4 shows that the postgraduate study offices were not fall within the comfort range during studying hours. It was observed that the state of temperature for offices are far from the thermal comfort of $26^{\circ} \mathrm{C}$ from the guideline given by Malaysian Energy Efficient Guideline (MEEG), thus hardly to achieve the thermal comfort during office hours according to MEEG. The Department of Standards Malaysia ${ }^{[8]}$ recommended indoor design temperature range from $23-26^{\circ} \mathrm{C}$.

Surveys of the human thermal response in South East Asia (SEA) produce the following equation (Auliciems' equation) for estimating thermal neutrality in base on the mean monthly dry bulb temperature $\mathrm{Tm}^{[31]}$. 
Am. J. Applied Sci., 6 (5): 943-951, 2009

Table 1: Measurements of ACH and Outside Air Quantities for Naturally and Mechanically Ventilated Study Office Middle of study office

\begin{tabular}{|c|c|c|c|c|c|c|}
\hline \multirow{2}{*}{$\begin{array}{l}\text { Study } \\
\text { Office }\end{array}$} & \multirow{2}{*}{$\begin{array}{l}\mathrm{ACH} \\
\left(\mathrm{h}^{-1}\right)\end{array}$} & \multirow{2}{*}{$\begin{array}{l}\text { Fresh air }(1 / \mathrm{s})^{\mathrm{a}} \\
\mathrm{D}=0.9 \mathrm{AC} / 3.6\end{array}$} & \multicolumn{2}{|l|}{ Design occupancy } & \multicolumn{2}{|l|}{ Actual occupancy } \\
\hline & & & No. of persons (Occ) & 1/s/Occ F=D/E & No. of persons $(\mathrm{Occ}) \mathrm{E}^{1}$ & $1 / \mathrm{s} / \mathrm{Occ} \mathrm{F}=\mathrm{D} / \mathrm{E}^{1}$ \\
\hline 1 & 1.7 & 33 & 3 & 11 & 5 & 6.6 \\
\hline 2 & 2.5 & 109 & 7 & 15.6 & 10 & 10.9 \\
\hline
\end{tabular}

$\mathrm{T} \mathrm{n}=17.6+0.31 \mathrm{~T} \mathrm{~m}$

It applies to both naturally ventilated and airconditioned buildings.

Regarding this equation the thermal neutrality for two study office were, $26.1^{\circ} \mathrm{C}$. The neutrality temperatures $\left(24.6, \quad 26.1^{\circ} \mathrm{C}\right.$ and $\left.27.4^{\circ} \mathrm{C}\right)$ for Malaysia $^{[10,12]}$ found earlier correspond well to $27.4^{\circ} \mathrm{C}$ ET* obtained in Thailand and $28.5^{\circ} \mathrm{C}$ in Singapore ${ }^{[19]}$.

The proposed neutral temperatures are higher than $24.5^{\circ} \mathrm{C}$ recommended by ASHRAE Standard 55. This finding is similar to the finding of other studies in Malaysia $^{[10,32]}$ and the surrounding regions ${ }^{[2,17,18,20,33]}$.

Evaluation of Air Exchange Rate (ACH): Figures 5 and 6 show the concentration decay profiles of postgraduate study offices, from which the $\mathrm{ACH}$ are determined. The measurements for two offices were carried out when the outside air velocity was $0.3 \mathrm{~m} / \mathrm{s}$; hence air infiltration could be neglected as the external wind pressure was low. The ACH and the fresh air quantities are computed and tabulated in Table 1.

It is seen from Table 1 that the air exchange rates are 1.7 and 2.5 and the amount of fresh air provisions are 11 and $15.6 \mathrm{l} / \mathrm{s} /$ person on the basis of design occupant density (10 m2/person) and 6.6 and 10.9 $1 / \mathrm{s} /$ person on the basis of actual occupancy for postgraduate study offices 1 and 2, respectively.

It is to be noted that these provisions except office 1 in actual occupancy are generally adequate based on current ASHRAE Standard 62 requirements of 10 $1 / \mathrm{s} /$ person and. It is worth note that based on design occupancy, outside air provision in comparison to actual occupancy are higher and in accordance to ASHRAE requirement for two offices.

Evaluation of age of air and Air Exchange Effectiveness (AEE): The AEE parameters are obtained from the fundamental data of age of air measurements recorded by the IAQ meter, which are presented in Table 2. The local age of air for office 1 and 2 was between 2224 and 1755 s or about 37 and 29 min, respectively. It means that the length of the time for fresh air to remain in the office is about 37 and 29

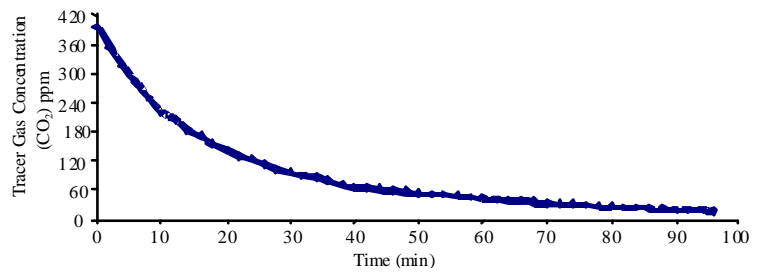

Fig. 5: Variation of local tracer gas concentration vs. Time for postgraduate study office 1

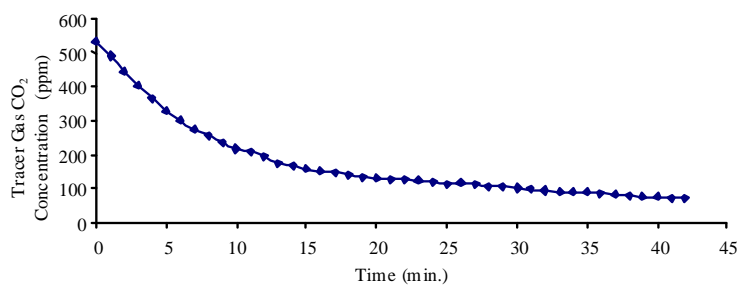

Fig. 6: Variation of local tracer gas concentration vs. Time for postgraduate study office 2

Table 2: Measurements of age of air and air exchange effectiveness for offices

Middle of Main Office Room

\begin{tabular}{llll} 
Study office & Exhaust, $\tau_{\mathrm{E}}(\mathrm{s}) \mathrm{G}$ & Local, $\tau_{\mathrm{L}}(\mathrm{s}) \mathrm{H}$ & Local $\varepsilon_{\mathrm{L}} \mathrm{G} / \mathrm{H}$ \\
\hline 1 & 2158 & 2224 & 0.97 \\
2 & 1738 & 1755 & 0.99 \\
\hline
\end{tabular}

min. When there is a uniform distribution of air over the office air-space, $\varepsilon_{\mathrm{L}}=1$.

$$
\mathrm{B}=\frac{\mathrm{A}}{\mathrm{H}}
$$

Where: $\mathrm{A}$ is the volume of room and $\mathrm{H}$ is the height of office. In the present work, the volume of the rooms 1 and 2 are $A=78$ and $174 \mathrm{~m}^{3}$ and their surface areas are $\mathrm{B}=30$ and $67 \mathrm{~m}^{2}$, respectively.

However, when there is a non-uniform distribution of air over the office air-space or in another word, some stagnant zones within office air-space, values of $\varepsilon \mathrm{L}$ are significantly less than 1 . A value less than 1.0 shows less than perfect mixing with some degree of 
Am. J. Applied Sci., 6 (5): 943-951, 2009

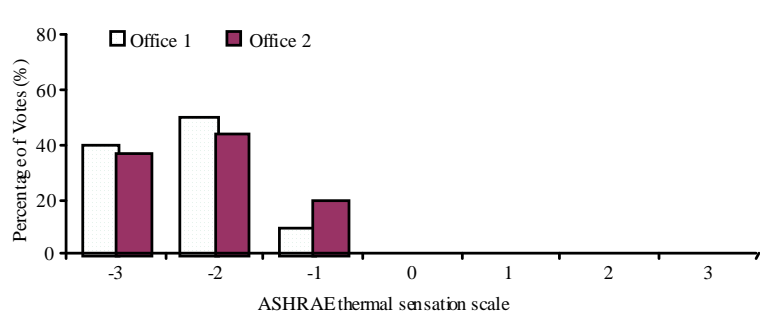

Fig. 7: Relative frequency of ASHRAE thermal votes for offices

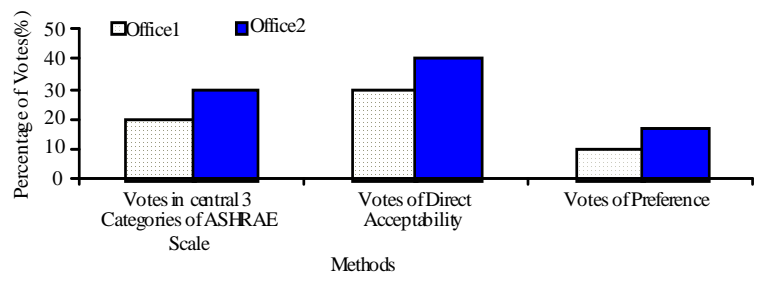

Fig. 8: Comparisons of various methods of assessing thermal acceptability for two offices

stagnation. A value of $\varepsilon_{\mathrm{L}}>1$ suggests that a degree of plug or displacement flow is present ${ }^{[34]}$. The local air change effectiveness at location for postgraduate study office 1 and 2 was found to be $0.97,0.99$, respectively and this implies that there was no short-circuiting of ventilation air on a global scale. The local air change effectiveness indicated a reasonably perfect mixed air in those conditions.

Evaluation of questionnaire: Figure 7 shows the profile of Thermal Vote cast on the ASHRAE scale for two offices. From the relative frequency of votes in each category can be seen that the thermal vote for offices centered on -2 to -3 . On the other hand, Fig. 8 gives a comparison of the various methods of assessing acceptability. By equating the central three categories of the ASHRAE 55 scale with the notion of acceptability, 10 and $20 \%$ of the occupants for offices 1 and 2, respectively are assumed to be satisfied with the thermal condition in their office. The direct votes of acceptability for study offices are 76 and $90 \%$ for two conditions. In contrast, the thermal preference scale appears to be only 40 and $56 \%$ of the respondents. Therefore, it is clear that there are people who vote beyond the center three category and yet find their environment acceptable. Different results can be obtained from different method of measurements and it is similar to other studies ${ }^{[2,35]}$.

Figure 9 and 10 explain the list of various adaptive actions commonly occurred in study offices and their

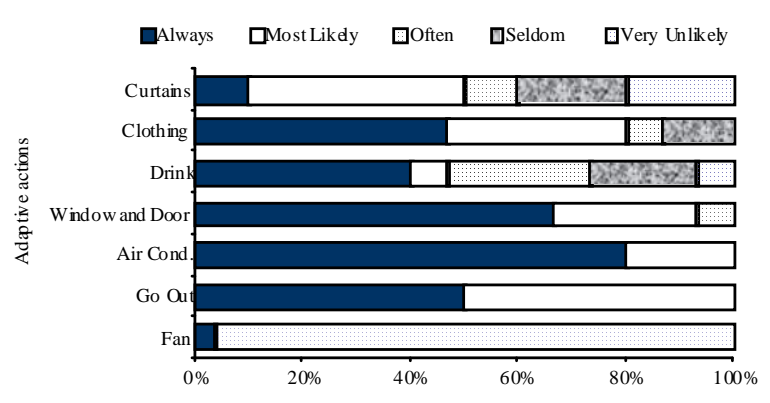

Fig. 9: Adaptive behavior-office 1

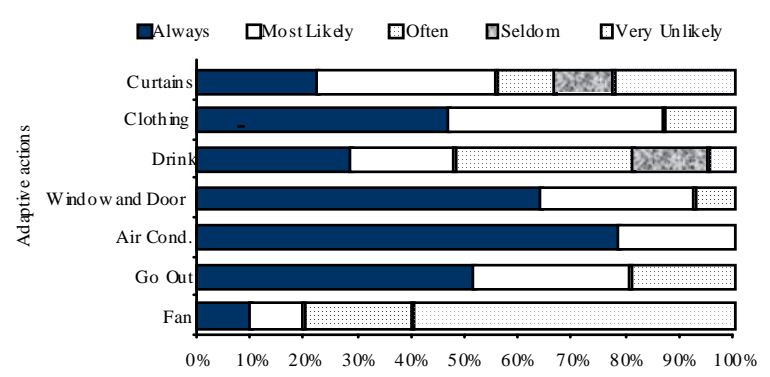

Fig. 10: Adaptive behavior-office 2

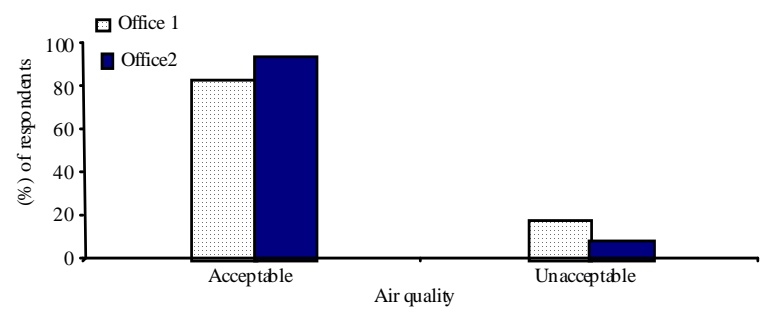

Fig. 11: Distribution of air quality

percentage of people who choose to employ them. The environmental control by turning off the air-conditioner is highly preferred by students for offices 1 and 2 with the percentages of 80 and $73.3 \%$, respectively. Other favoured adaptive actions are opening the windows and door with the percentage of 66.6 and 60 for offices 1 and 2, respectively. Going out to warmer places with the percentage of 50 and 53.3 for offices 1 and 2, respectively is another favorable action. Putting on extra clothes is another favorable action with $46.6 \%$ for two offices.

Figure 11 shows the opinions of students on the air quality in two offices. Staffs were satisfied with the air quality, therefore, air quality in two office rooms were within tolerable limits for students. ASHRAE Standard 62 defines acceptable air quality as conditions in which more than $80 \%$ of people do not express dissatisfaction. 
Am. J. Applied Sci., 6 (5): 943-951, 2009

\section{CONCLUSION}

Objective measurement of two postgraduate study offices showed that they had not thermal conditions falling within the comfort zone of ASHRAE standard 55 and ISO 7730.

It is seen that the outside air exchange rates values are sufficient based on design and actual occupancy for office 2 but it is not sufficient based on actual occupancy in office 1 .

In the case of air exchange effectiveness, it is observed that the AEE values in two offices are close to one implying no serious problems of short circuiting of ventilation air in these offices and that the ventilation air is well mixed.

The neutrality temperatures are higher than the ASHRAE Standard 55-1992. The Result of this study like previous studies in Malaysia and south east of Asia suggest a wider thermal comfort range for Malaysian than that proposed by international standards, i.e., ASHRAE Standard 55-92, which indicates that Malaysian and people in hot and humid climate are acclimatized to much higher environmental temperatures. The thermal votes for two offices centered around (-2) to $(-3)$.

In terms of the use of climatic control to modify the indoor environment, it is found that the turning Airconditioner off, opening of windows and door, going out and putting on extra clothes were high in two offices. The study discussed the occupant's behaviour in utilizing the various environmental and personal controls to make themselves thermally comfortable. Adaptive actions have contributed in some positive ways to the higher level of thermal comfort. When the occupants have the freedom to modify the environment and make necessary adjustment (Such as: windowsdoor opening arrangements), they always use them to compensate for the less comfortable thermal conditions.

The information obtained from questionnaires show that the air quality in two offices are satisfactory. The information obtained from the measurement and questionnaire show that offices have good air quality.

\section{REFERENCES}

1. Ahmad, A., 2004. Case study: Thermal comfort study demonstration low energy office (LEO), MSc. Thesis, University of UKM, Malaysia.

2. Wong, N.H. and S.S. Khoo, 2003. Thermal comfort in classrooms in tropics. Energy Build., 35: 337-351.
3. Loomans, M.G.L.C. 1998. Measurements at and simulations of the (improved) desk displacement ventilation concept. Proceedings of the Roomvent'98: 6th International Conference on Air Distribution in Rooms, held June 14-17 1998 in Stockholm, Sweden, pp: 241-248.

4. ASHRAE Standard 62-1989. Ventilation for acceptable indoor air quality. USA: American Society of Heating and Air Conditioning Engineers Inc.

5. ASHRAE, 1992. Thermal Environmental Conditions for Human Occupancy. Standard 551992. American Society of Heating, Refrigerating and Air-Conditioning Engineers, Atlanta, USA.

6. ISO 7730, 1994. Moderate Thermal EnvironmentsDetermination of the PMV and PPD Indices and Specifications for Thermal Comfort, International Organisation for Standardisation.

7. Malaysia, 1989. Guidelines for Energy Efficiency in Buildings. Ministry of Energy, Telecommunication and Posts Malaysia.

8. Malaysian Standard (MS). MS 1525, 2001. Code of Practice on Energy Efficiency and Use of Renewable Energy for Non-residential Buildings. Department of Standards Malaysia.

9. Zainal, M. and C.C. Keong, 1996. Thermal comfort and energy conservation in factory buildings. Proceedings of the 7th International Conference on Indoor Air Quality and Climate, held July 21-26, Nagoya, Japan, 2: 601-606.

10. Abdul Rahman, S. and K.S. Kannan, 1997. A study of thermal comfort in naturally ventilated classrooms: Towards new indoor temperature standards. Asia Pacific Conference on the Built Environment, 3-6 Nov., Kuala Lumpur, Malaysia.

11. Abdul Shukor, A.M. and A. Young, 1993. Thermal comfort study as an aid to determine energy savings in buildings in Malaysia. In Proceedings of Energex 93, The 5th international energy conference, Oct. 18-22, Seoul, South Korea, pp: 261-267.

12. Sabarinah, S.H., Ahmad, 2005. Thermal comfort and building performance of naturally ventilated apartment building in the Kelang valley: A Simulation Study. Proceedings of the Energy in Buildings (Sustainable Symbiosis) Seminar, May 10-11, Subang Jaya, Malaysia. Universiti Teknologi MARA Publication Centre (UPENA), pp: 115-132.

13. Z.M. Zain, M.N. Taib and S.M.S. Baki, 2007. Hot and humid climate: Prospect for thermal comfort in residential building. Desalination, 209: 261-268. 
14. Nugroho, A.M., M.H. Ahmad and D.R. Ossen, 2007. A preliminary study of thermal comfort in Malaysia's single storey terraced houses. JAABE, 6: 175-182.

15. Webb, C.G., 1952. On some observation of indoor climate in Malaya. J. Institut. Heat. Ventilating Eng., 189-195.

16. Ellis, F.P., 1952. Thermal comfort in warm humid atmosphere observations in a warship in the tropics. J. Hygiene, 50: 415-432.

17. Wong, N.H., H. Feriadi, P.Y. Lim, K.W. Tham, C. Sekhar and K.W. Cheong, 2002. Thermal comfort evaluation of naturally ventilated public housing in Singapore. Build. Environ., 37: 1267-1277.

18. De Dear, R., K.G. Leow and A. Ameen, 1991a. Indoor climate and thermal comfort in the humid tropics-part I: climate chamber experiments on temperature preferences in Singapore. ASHRAE Trans., 97: 874-879.

19. De Dear, R., K.G. Leow and S.C. Foo, 1991. Thermal comfort in the humid tropics: Field expriment in air-conditioned and naturally ventilated buildings in Singapore. Int. J. Biometeorol., 34: 259-265.

20. Busch, J.F., 1992. A tale of two populations: Thermal comfort in air-conditioned and naturally ventilated offices in Thailand. Energy Build., 18: 253-243.

21. Karyono, T.H., 2000. Report on thermal comfort and building energy studies in Jakarta-Indonesia. Build. Environ., 35: 77-90.

22. Khedari, J., N. Yamtraipat and J. Hirunllabh, 2000. Thiland ventilation comfort chart. Energy Build., 32: 245-249.

23. Cheong, K.W. and K.Y. Chong, 2001. Development and application of an indoor air quality audit to air-conditioned building in Singapore. Build. Environ., 36: 181-188.

24. Cheong, K.W.D., H.Y.T. Lau, 2003. Development and application of an indoor air quality audit to an air-conditioned tertiary institutional building in the tropics. Build. Environ., 38: 605-616.

25. Wong, N.H. and S.S. Khoo, 2003. Thermal comfort in classrooms in the tropics. Energy Build., 35: 337-351.
26. Cheong, K.W.D., W.J. Yu, S.C. Sekhar, K.W. Tham and R. Kosonen, 2007. Local thermal sensation and comfort study in a field environment chamber served by displacement ventilation system in the tropics. Build. Environ., 42: 525-533.

27. Rhasbudin, S.M., M.Z.M. Yusof, A.M. Leman and A. Hussain, 2005. The effectiveness of underfloor air distribution system in controlling thermal comfort and indoor air quality. Proceedings of the Energy in Buildings (Sustainable Symbiosis) Seminar, May 10-11, Subang Jaya, Malaysia, pp: 43-58.

28. Sekhar, S.C., K.W. Tham and D. Cheong, 2002. Ventilation characteristics of an air-conditioned office building in Singapore. Build. Environ., 37: 241-255.

29. Sekhar, S.C., K.W. Tham, K.W. Cheong, 2003. Indoor air quality and energy performance of airconditioned office buildings in Singapore. Indoor Air, 13: 315-331.

30. Feriadi, H. and N.H. Wong, 2004. Thermal comfort for naturally ventilated houses in Indonesia. Energy Build., 36: 614-626.

31. Auliciems, A., 1981. Towards a psychophysiological model of thermal perception. Int. J. Biometeoroly, 25: 109-122.

32. Ahmad, S. and N. Ibrahim, 2003. A study on thermal comfort in classrooms in Malaysia. Proceedings of the PLEA 2003- The 20th Conference on Passive and Low Energy Architecture, Nov. 9-12, Santiago, Chile.

33. De Dear, R., K.G. Leow and A. Ameen, 1991b. Indoor climate and thermal comfort in the humid tropics-part II: climate chamber experiments on thermal acceptability in Singapore. ASHRAE Trans., 97: 880-886.

34. ASHRAE, 2005. ASHRAE HandbookFundamental, American Society of Heating, Refrigerating and Air-Conditioning Engineers, Atlanta, USA.

35. Kwok, A.G. and C. Chun, 2003. Thermal comfort in Japanese schools. Sol. Energy, 74: 245-252. 